\title{
Spring and All
}

By the road to the contagious hospital

under the surge of the blue

mottled clouds driven from the

northeast - a cold wind. Beyond, the

waste of broad, muddy fields

brown with dried weeds, standing and fallen

patches of standing water

the scattering of tall trees

All along the road the reddish

purplish, forked, upstanding, twiggy

stuff of bushes and small trees

with dead, brown leaves under them

leafless vines -

Lifeless in appearance, sluggish

dazed spring approaches -

They enter the new world naked,

cold, uncertain of all

save that they enter. All about them

the cold, familiar wind -

Now the grass, tomorrow

the stiff curl of wildcarrot leaf

One by one objects are defined -

It quickens: clarity, outline of leaf

But now the stark dignity of

Entrance - Still, the profound change

has come upon them: rooted, the

grip down and begin to awaken

William Carlos Williams (1923)* 